\section{Study Group on Special Librarianship}

THe Assogtation of Special Libraries and Information Burraux is proposing to repeat the successful experjnent of last year of organising a study group on special librarianship in collaboration with the Library Association. This will be held at Chaucer House, London, during August 12-17. There will be lectures in the mornings, and in the evenings talks and discussions on special topics, while in the afternoons it is hoped to arrange visits to a number of special libraries. Full details and application forms can be obtained from the Director, ASLIB, 52 Bloomsbury Street, W.C.1.

\section{University of Lopdon}

Dr. A. D. Rors has been appointed to the University chair of civil engineering tenable at King's College fyóm October 1; since 1935 he has been lecturex in the Department of Civil and Mechanical Engineering at the College.

Mr. S. H. Beaver, lecturer in geography at the London School of Economic and Political Science, has been appointed to the Sir Ermest Cassel readership in economic geography tenable at the School.

The degree of D.Sc. of the University has been conferred on : Mr. J. F. Kirkaldy (King's College) ; Mr. S. Maulik (Imperial College of Science and Technology); Mr. B. S. Rao (University College); Mr. T. Small (King's College); Mr. A. R. Collar (external student).

\section{Institution of Etectrical Engineers: Awards}

THE Copncil of the Institution of Electrical Engineens has made the following awards of premiums for papers read, or accepted for publication, during the session 1945-46: Institution Premium, Dr. F. C. Whliams. John Hopkinson Premium, J. F. Coales, J. C. Calpine, and D. S. Watson. Non-Section Premiums, R. H. Coates and B. C. Pyle (Ayrton Premium); J. C. Read (Llewellyn B. Atkinson Premium); F. Ashworth, W. Needham, and Dr. R. W. Sillars (Extra Premium). Installations Section Premiums, R. Grierson and Forbes Jackson (Crompton Premium); Dr. A. J. King (Swan Premium); J. C. Macfarlane, Dr. J. W. Macfarlane, and W. I. Macfarlane (Extra Premium). Measurements Section Premiums, Dr. A. L. Whiteley (Silvanus Thompson Premium); C. G. Garton (Mather Premium); Dr. A. Fairweather (Extra Premium). Radio Section Premiums, Dr. H. G. Booker (Duddell Premium); E. C. Cherry (Ambrose Fleming Premium); C. F. Booth and F. J. M. Laver (Extra Premium); R. J. Clayton, Dr. J. E. Houldin, Dr. H. R. L. Lamont, and W. E. Willshaw (Extra Premium); Dr. R. A. Smith (Extra Premium); E. C. S. Megaw (Extra Premium); O. L. Ratsey (Extra Premium); R. J. Dippy (Extra Premium); Dr. N. R. Campbell and V. J. Francis (Extra Premium). Transmission Section Premiums, Dr. L. G. Brazier (Sebastian de Ferranti Premium); A. G. Ellis (John Snell Premium); P. J. Ryle (Extra Premium). Fahie Premium, F. C. McLean and F. D. Bolt. Paris Exhibition (1881) Premium, J. S. Pickles and W. H. Wills. Webber Premium, Dr. D. H. Parnum. Willans Premium (awarded triennially by the Institution of Electrical Engineers and the Institution of Mechanical Engineers), R. W. Biles and G. W. Maxfield, for their paper on "Standards of Performance of Generating Plant based on Five Years Operating Data".

\section{Announcements}

Dr. John A. Fleming, director since 1935 of the Department of Terrestrial Magnetism of the Carnegie Institution of Washington, has retired, but will remom at the Institution temporarily as adviser in governmental and international scientific relations. It will be recalled that Dr. Fleming was awarded the Charles Chree Medal for 1945 of the Physical Society of London (see Nature, December 1, 1945, p. 658). Dr. Fleming will be succeeded by Dr. M. A. Tuve, chief physicist of the Department.

THE Institution of Chemical Engineers is establishing two bursaries, each of $£ 100$ a year, to assist students to obtain a bachelor's degree in chemical engineering. Candidates must have reached the higher school certificate or intermediate B.Sc. or equivalent standard; they may have spent a period In industry or in H.M. Forces. The bursaries will be tenable for three years. Applicants should be British subjects by birth. Applications should be addressed to the Joint Honorary Secretaries, Institution of Chemical Engineers, 56 Victoria Street, London, S.W.1, by whom they must be received not later than August 1.

THE Trustees of the Busk studentship in aeronautics, founded in memory of Edward Teshmaker Busk, who lost his life in 1914 while flying an experimental aeroplane, have awarded the studentship for the year 1946-47 to Richard Peter Boswell, of Hawker Aircraft, Ltd.

THE four Exhibition Galleries of the Imperial Instityte, London, have been re-opened to the general pubfic from $10 \mathrm{a.m}$. until $4.30 \mathrm{p.m}$. on weekdays. There is a display of Empire films in the cinema of the Institute a.r.h day at 3.30 p.m.

The Present Question Conference (Secretariat, 37 Middleway, London, N.W.11) will meet at University College, Exeter, during August 20-27. The purpose of this Conference is to consider in a practical way various approaches to the question: "Is the present chaos caused by lack of scientific planning, or by failure to recognize the reality of Spirit ? The answer may be found through a deeper understanding of the nature of man." It is believed that an experimental approach will prove of value in obtaining a synthesis between the opposing points of view of science and religion. The announcement is signed by, among others, Dr. W. R. Matthews, Dr. Stephen Neill and Prof. A. D. Ritchie.

A USEFul 64-page pamphlet by G. A. Campbell and T. F. West orty (ed "The Truth about D.D.T." has recently foec ifsued by Findon Publications, Ltd. (1s) 018 origmal discovery of this compound is trace 1 f fom when it was achieved in Basle, many is tra agd, up to its most recent applications, whether inforborfted in dusts, spray fluids or mixed with paints, distemper, ete. For those wishing to know the essential facts concerning this insecticide and its potentialities, this simply written account will give the desired information.

IN the graph accompanying the communication entitled 'Dielectric Behaviour of 'Polythene' at Very Aigh Frequency" by J. G. Powles and W. G. Oalks in Nature of June 22, p. 840, the wave-length scale has inadvertently been shifted to the left; the right-hand end of the scale $(1 \mathrm{~cm}$.) should be vertically below $3 \cdot 33 \times 10^{10}$ on the frequency scale. 